\title{
Scaffolding in Learning to Write: A Focus on Learners and Teacher in Rural Area \\ llyana Jalaluddin
}

Universiti Putra Malaysia, 43400 Serdang Selangor, Malaysia

ilyana@upm.edu.my

\begin{abstract}
This study focuses on rural area learners' learning process, and the teacher's roles in developing the rural learners' writing skills. Specifically, this study aims to investigate how teacher assists the students in learning to write, and following that, this study then aims to understand how teacher's assistance affects students' writing skills. The participants of this study consisted of three fourth former students and their English teacher. In order to gather information about the teacher's assistance and its effect on learners' writing skills, two types of data were collected. Firstly, non-participant classroom observation was carried out for six months where the researcher observed and recorded each activity in the classroom. Secondly, all of the students' written works during each activity were compiled and the content was analyzed to see the changes. One essay entitled 'My father' will be used for the discussion of this paper. Finding showed that students managed to improve their sentences in the essay once the teacher assisted them through class discussion and individual comments.
\end{abstract}

\section{Indexing terms/Keywords}

Teacher's assistance, writing skills, rural area learners.

\section{Academic Discipline And Sub-Disciplines}

Education; Language development; Writing skills

\section{SUBJECT CLASSIFICATION}

English Language

\section{TYPE (METHOD/APPROACH)}

Qualitative approach: Classroom observation, content analysis, case study

\section{Council for Innovative Research}

Peer Review Research Publishing System

Journal: INTERNATIONAL JOURNAL OF RESEARCH IN EDUCATION METHODOLOGY

Vol 6, No.2

www.ijrem.com, ijremeditor@gmail.com 


\section{INTRODUCTION}

The issue of rural learners' English proficiency has always been of concern among Malaysian teachers, academics, and Ministry of Education officials because these students lack of proficiency in English and unable to use the language well. This is especially so for rural school students, whose failure rate in national standardized English examinations is twice that of their urban counterparts (Ratnawati \& Ismail, 2003; Norazman, Faruk Muhammad \& Fatimah Puteh 2005; Ministry of Education, 2005, 2008). The 2005 School Certificate Examination Report on English Language Paper 2 revealed that the majority of the candidates have yet to master writing skills in English at the required level (Samuel \& Zaitun Bakar, 2008). In 2008, MOE has identified writing as the main obstacle for students in getting good marks either at PMR or SPM level. This is because the writing component bears 85 marks of the total marks at SPM level and 60 marks at PMR level. Year after year, examiners have expressed with great dismay the fact that after having learnt English for eleven years, Malaysian rural students in most cases failed to produce even a short paragraph of intelligible writing (Samuel \& Zaitun Bakar, 2008). In addition, many rural school students also have difficulty understanding English, and a few are able to use English in simple conversation (Ratnawati \& Ismail, 2003). The resulting disparity in English language proficiency levels between urban and rural students has contributed much to the urban-rural divide (Assoc Prof Dr. Padmani Mildred Thiyagarajah, 2003).

A lot of effort and suggestions have been put forward to attract the learners from rural areas to learn and master the English language. One of the government programs is the First Step Program which emphasizes on reading and writing to help rural students improve their command of English. However, MOE reported that "the effectiveness of the program and the quality of teachers teaching the language in rural schools is still a big question" (The Star, November 12, 2008, p.19). This is because "the command of English in rural schools, in Teluk Intan specifically, is still poor" (The Star, November 12 , 2008). Malaysian students still see writing as a difficult task and there are very few social uses for writing in English in the school (Chitravelu et al, 2005). According to Samuel \& Zaitun Bakar (2008, p.1);

Students in rural schools generally find it difficult to maintain their interest in English language learning as English is not seen as important for their immediate need. Teachers on their part are unable to sustain students' genuine interest in continuing to learn English and to use the language once the examination is over.

Overall, studies been conducted in previous years give a general picture of rural language learners' performance, difficulties and obstacles in an effort to learn English especially writing. Given the difficulties and performance of the rural language learners, it is thus necessary to focus on rural learners and understand how teacher's assistance able to affect the learners' skills in writing. Nevertheless, this study will focus specifically on writing skills as this is the most skill that the rural students find difficult to learn. This study will focus on teacher's assistance as the independent variable in order to see how far it can affect the rural learners' skills in writing.

\section{THEORETICAL FRAMEWORK}

\section{Socio-cultural theory in writing}

The development of writing competence in a socio-cultural model shows that writing development closely aligned to another aspect of instructional discourse that is contextualized through effective teacher's pedagogical practice. Englert, Mariage and Dunsmore (2008, p.209) posited that "socio-cultural perspective emphasize the importance of the provision of co-participation and guided practice as a prominent feature in writing activity settings where expertise is distributed, practiced, and shaped in order to produce a common product or artifact". This means that what begins as a teachercentered discourse in authentic writing activity is succeeded by an interactive and collaborative discourse in which mental activity is distributed and shared between the teacher and student participants (Englert, Mariage \& Dunsmore, 2008).

Gallagher (1999) points out that there are three ways these cultural tools can be passed from one individual to another in writing process. The first one is imitative learning, where one person tries to imitate or copy another. Imitation in the ZPD is unlike copying or mimicking of what the teacher appears to do but it is a complex activity in which the novice is treated not as a repeater but as a communicative being (Lantolf, 2000). The second way is by guided writing which involves remembering the instructions of the teacher and then using these instructions to self-regulate. The final way that cultural tools are passed to others is through collaborative learning, which involves a teacher or other capable peers who strive to understand each other and work together to learn specific writing skills. Basically, Vygotsky's theory suggests that development depends on interaction with teacher and the tools that the culture provides to assist them to form their own view.

The assistance provided by the teacher is actually be represented by the concept of scaffolding proposed by Vygotsky (1978). In other words, it refers to the assistance and interactional support given by an adult in the zone of proximal development. "Scaffolding is sensitively tuned to what the learner presently understands, getting him to concentrate on what he can/she can manage while the teacher fills in the parts that the learner cannot do" (Smith, A., 1997, p.24). Accordingly, scaffolding provides a facilitating context which allows a writing task to be completed. As Donovan \& Smolkin (2008) explains, judicious questioning and commenting about a piece of writing provides the scaffolding for the writer's ideas to be further developed and clarified. In the end, the writer is better able to develop and clarify without the same level of support. Kramsch, as cited in Lantolf (2000, p.22) proposes that learning a second language is not about simply learning new linguistic forms, but it is also about learning how to construct, exchange and interpret signs that have been 
created by someone else. She emphasized that through collaborative interaction about writing that ESL learners will be able to construct their own writing. It was also found that the changing quality of scaffolding in writing classroom was able to help low-income ethnic minority learners where they became more attentive, reflective, actively involved in class discussion and used elaborate language structures in writing (Lantolf, 2000).

Vygotsky's notion of scaffolding indirectly lends a picture to teaching of writing that assistance in the form of interaction or conversation between teacher as a more capable individual and the writers is important in molding their writing skills and confidence in pursuing the task. As Tharp (1994, p.156) notes, "The critical form of assisting learners is through dialogue, through the questioning and sharing of ideas and knowledge that happens in instructional conversations.... To truly teach, one must converse, to converse is to teach". The presence of social activity is important here in helping learners to learn because it makes existing knowledge available for introspection, helps learners to change their knowledge and fit into what they already know (Smith, J., 1997, p.200). Thus, if interaction or feedback is given during writing process, students indirectly will be aware of readers' responses as their writing process received feedback from other people.

In addition, Vygotsky's focus on the interaction between the teacher and learner leads to a concept which he called as "the zone of proximal development". In other words, this is the 'place' where instruction and learning can take place.

In Vygotsky's words, the zone of proximal development "is the distance between the actual developmental level as determined by independent problem solving and the level of potential development as determined through problem solving under adult guidance or in collaboration with more capable peers" (cited in Daniels, 2001, p.57).

This ZPD concept begins as Vygotsky believed that children's development appears on two planes which are interpsychological and intrapsychological category. Interpsychological means that it appears between people and, intrapsychological is within the child itself. Along the way, internalization helps to transform the process itself and changes its structure and function. Lantolf and Thorne (2006) later point out two important issues from these two planes; that cognitive development is the result of social and inter-personal activity which in turn becoming the foundation for intrapersonal functioning, and this process involves internalization. Internalization is a process where children learn first through people as interpsychological category and then inside the child as an intrapsychological category (Donovan \& Smolkin, 2008).

\section{Teaching writing using ZPD concept}

The notion of zone of proximal development in the way mirrored the process-language approach to teaching reading and writing. Tharp and Gallimore (1988) defined teaching from sociocognitive perspective as consisting of assisted performance, and teaching is occurring when performance is achieved with assistance. Therefore, the teacher's task is to provide for collaborative interaction, to share understanding, and to provide assisted performance (an activity setting) within the context of a goal-directed action. The teacher is crucial here because it is the instructing voice of the teacher that eventually becomes self-instruction for the learner as Tharp and Gallimore $(1988, p .57)$ posited that "the teacher acts as the voice of the learner in transition from apprentice to self-regulated performer". Nevertheless, the performance assistance provided by the teacher is gradually decreased as the learner's self-regulation will increase over the time (Gallimore \& Tharp, 2000). To use Vygotsky's term, there should be a move from the social plane to the psychological plane, from the intermental to the intramental, from the socially regulated to the self-regulated. This definition of teaching indirectly implies that learning to write should be a developmental progress through the reciprocal influence of child and social environment, while unfolding the potential of the learner gradually. Thus, writing progress through the zone of proximal development should be gradually from assisted performance to unassisted and self-regulated performance.

Willhelm, Baker and Dube (2001) proposed a teaching model based on Vygotsky's notion of zone of proximal development where they have divided the zone into two areas which are zone of actual development (ZAD) and zone of proximal development (ZPD). What a child can do alone and unassisted is a task that lies in what Vygotsky calls the zone of actual development (ZAD) (Willhelm, Baker \& Dube, 2001). When a teacher assigns a task and the students are able to do it, the task is within ZAD. Nevertheless, anything that the child can learn with the assistance and support of a teacher, peers and the instructional environment is said to lie within the ZPD. According to Willhelm, Baker and Dube (2001), a child's new capacities can only be developed in the ZPD through collaboration in actual, concrete, situated activities with an adult or more capable peer. With enough assisted practice, the child internalize the strategies and language for completing this task, which then becomes part of the child's psychology and personal problem-solving repertoire. When this is achieved, the strategy then enters the student's zone of actual development, because she is now able to successfully complete the task alone and without help and to apply this knowledge to new situations she may encounter (Willhelm, Baker \& Dube, 2001).

\section{METHODOLOGY}

This study employed a case study approach to explore the effect of teacher's assistance on rural area learners' writing skills. This study adopted a case study because it allowed the researcher to focus closely on the subjects and examine the issue in depth rather than spread the attention over a broader domain. Data had been collected once a week until the researcher had reached the point of saturation. Specifically, the researcher had collected the data for 5 months.

\section{Classroom observation for teacher's assistance}


The researcher observed both classes once a week in order to get a detail description of the teacher's assistance in the classroom. The purpose of the observation is to gather information on aspects of the teacher's assistance that would promote or impede skills in writing. During each observation, the researcher sit at the back of the classroom to observe and take note of what were being said or done by the teacher and students. In addition, video recorder was also used to ensure the researcher would not miss any important data. This descriptive technique is chosen in preference to more objective and restrictive techniques such as rating scales and checklists because "rating scales or checklist must use considerable judgment to infer to proper rating, hence descriptive observations system is more reliable than rating system observation as the somewhat subjective judgment is not required" (Wiersma \& Jurs, 2005, p.340).

\section{Content analysis}

Samples of compositions and all written exercises were collected from each of the participants. Two of the learners' writing task were evaluated in detail by two readers namely the researcher and the English teacher. The evaluation was based on the holistic marking scheme as prescribed by the Malaysian Examination Syndicate. Basically, there are two categories which are directive and continuous writing, and each carries 35 marks and 50 marks respectively. Directed writing will be reports, speeches, letters, stories from guidelines, descriptions of processes/procedures and describing. On the other hand, continuous writing refers to narrative, descriptive, factual, argumentative, discussive and reflective compositions. Selecting two or more samples of materials will allow the researcher to make comparison and a kind of equivalent forms reliability could be done (Fraenkel \& Wallen, 2001). Once both readers finished marking the essays, they were compared to see any differences in grading and to finalize the marks. According to Fraenkel \& Wallen (2001), by assessing the agreement between two or more evaluators, it would be useful to know how the categorizations made by the researcher agree with the categories or not.

\section{FINDING}

\section{Teaching process}

The students were asked to write an essay entitled 'My father' on $13^{\text {th }}$ June 2009 in the class within one hour. The teacher then spent two weeks to teach the essay 'My father' and there were two periods (with one hour each) where the teacher specifically assisted the students. The two periods can be categorized as two stages below;

\section{Stage 1 ( $8^{\text {th }}$ July 2009)}

Initially, the teacher gave back the written work to the students and began with general comments. She firstly explained the major mistake that was sentence structure which affected the meaning of the sentence. Secondly, she focused on grammar part specifically present tense, article, subject verb agreement, pronoun, and preposition. She explained the rules for each part of speech by giving examples and asked students questions. Students were then given 10 minutes to read her comments and exchanged with their friends to see how their friends wrote. Each student received very specific comments and the teacher pointed out why the sentences were wrong. The teacher also circled and underlined each wrong words or phrases in the students' writing. For example;

Farah (Student A)

Teacher commented that her sentence 5, 6, 8 and 9 were unclear and needed to be elaborated. In terms of grammar, Farah needed to improve on the present tense, articles, subject-verb agreement and the preposition forms. Farah tended to write her description of her father in past tense and omitted the article 'the' after each specific noun. She was also consistently used pronoun 'he' with plural verbs such as 'like, are' throughout the essay.

Haslina (Student B)

Haslina received comments that her sentences (no $3,5,11,12,14,15$ ) were 'topsy-turvy'. The teacher also asked her to rephrase sentence 12,13 and 14 as the sentences were not written properly though the meaning was there. Besides that, Haslina also needed to rephrase sentence 10,11 and 15 as the teacher couldn't understand the meaning at all. In term of grammar, the teacher pointed out that she had too many subject verb agreement mistakes and wrong choices of words especially in sentence $1,4,6$ and 8 .

Siti Aishah (Student C)

The teacher specifically stated that her sentence 1 need to be elaborated more to make the story more interesting. The teacher also mentioned that her sentence $5,9,13,15,17,18,19,21,25$ and 26 were not very well-organized. In terms of grammar, Aishah needed to improve especially on subject verb agreement and to+verb.

After the students had read the teacher's comments (10 minutes), the teacher asked the students to try corrected their essay. While the students were correcting their essays, the teacher walked around the class to help and answered any questions regarding the comments given. For example, Student A was informed by the teacher that the word she used was wrong when she wanted to correct her sentence;

The teacher looked at Farah and points out that the word is wrong. Farah asks the teacher why the teacher has circled her word. Teacher explains that the sentence is incomplete. Teacher tells Farah that she used the word 
'weird' but not referring to any noun. Teacher explains that 'weird' is an adjective, so there should be a noun after that. Farah said that she actually means 'janggut' in English but doesn't know the spelling. The teacher asks whether she means the long bushy or the short one. Farah said 'janggut' short one. The teacher asks the class to guess the word short 'janggut' in English but the class doesn't know the word in English. The teacher then gives clue that the word starts with the letter ' $g$ ' but nobody can give the answer.

Student B and C however didn't asked any questions to the teacher and chose to work on their own. They only looked at other students' essays and compared with their essays.

\section{Stage $2\left(15^{\text {th }}\right.$ July 2009)}

In the second stage, the teacher then started commenting the students by specifically asked the students individually. She gave a handout consisting of 35 sentences taken from the students' essay 'My father' and asked the students one by one to find the errors and correct it. The teacher called this learning as 'sentence surgery' where the students need to respond by giving suggestion on how to correct the sentences. For example;

1005am: Teacher reads sentence 10 'He carry his responsibilities as family monitor as best as he can'. Noran points out that 'carry' should be 'carries'. The teacher asked why and Noran explained that 'he' is singular. Teacher added that if singular, the verb should come with 'es','ies' or 's' Then Farah suggests changing 'family monitor' to 'as a head of the family' and the teacher asks the class to use other words beside 'head'. Noran suggests 'leader' and the teacher accepts her answer. The boy then suggests to change 'can' to 'could' and the teacher accepts it. The class asks why use past tense 'could' even though the sentence is in present tense but the teacher says that she will explain about it in detail in the next class.

1005am: Teacher continues with sentence 11 'he don't like to wasted his time'. Teacher reminds the class that after 'to' it should be root word, and singular 'He' like in sentence 10.

943am: Teacher continues with sentence 6 'My father has a family with many people'. Teacher explains that there is wrong choice of word in the sentence. Farah raises hand and says change 'family with many people' to 'big family'. Teacher agrees and says that it is more specific and clear.

945am: Teacher reads sentence 6 'My father grow a farm' and explains that the meaning is unclear. Farah raises her hand and says that is her sentence. She explains that what she meant is 'grew up in a farm'. Teacher agrees and asks other students to change to 'grew up in a farm'

From the example, it showed that the teacher used the students' works to teach writing and showed the correct way to write it. She showed the sentence to the class and asked the students about the grammar mistakes like verb after 'to' and subject verb agreement for 'he'. From the students' responses, she managed to explain why the verb for 'he' should come with 'ies' or 's'. She also used Farah's essay to show what she meant by vague description and demonstrated how they should present their ideas.

\section{IMPROVEMENT IN WRITING}

On $16^{\text {th }}$ July 2009 , students were asked to submit their final draft for 'My father'.

\section{Farah (Student A)}

Through the discussion and comments given by the teacher in class, Farah managed to find the appropriate words to express her ideas. For example, Sentence 6 'My father has many people in family and he had grown in the farmer family', and Sentence 5 'He also has weird and moustache'. By discussing with the class and teacher, she then knew that the word 'people' is general and she narrowed it down by changing the sentence to 'My father has many siblings in his family' for her final draft. Though she suggested 'big family' during the discussion on $15^{\text {th }}$ July 2009 , she nevertheless used the word 'siblings' in her final draft. This showed that she finally understood the word 'people' is too general and should be related to 'family'. Furthermore, she also managed to correct her sentence by changing the word 'weird' after she discussed with the teacher and class. The teacher assisted her by raising the question of 'do you mean janggut or adjective weird'. From here, Farah then explained to the teacher that she meant short 'janggut'. Teacher gave clue that the word started with ' $g$ '. In her final draft, Farah managed to change the sentence to 'He has a goatie and moustache'.

\section{Haslina (Student B)}

Haslina, though quiet in the class discussion, she managed to rephrase her sentence as suggested by the teacher. Her teacher commented that her sentences were so topsy-turvy' and didn't make any sense. For example, 'Father say no bequest can father inheritor to you but just knowledge only bequest which precious to you and just who have a high knowledge people will see' (Sentence 10). In class, teacher showed sentence 10 and asked the class to correct it. She also raised the question 'What do you mean? Do you mean to say that your father puts great importance in education?'. Through the discussion then Haslina got suggestion 'there's nothing precious than knowledge'. However, in her final draft she only made a general statement that is without specifying the advice that the father gave. Haslina changed the sentence to 'He also always gives me advise about anything'. Though the changes was not as suggested by the class, Haslina still managed to come out with a more short and direct to the point sentence compared to first draft. She also managed to correct her subject verb agreement 'He...gives' after the teacher mentioned generally that there were many subject verb agreement errors.

\section{Siti Aishah (Student C)}


Aishah managed to change her sentence 1 'He always wear towel at home' after the teacher asked 'what if there is a guest, does h still wear towel?'. She changed it to 'Sometimes, he just wears towel at home' in her final draft. It showed that teacher's question made her realized the logic behind her sentence. In addition, this sentence also showed that she could use the verb 'wear' correctly though the teacher didn't specifically point out that the verb 'wear' is wrong in term of subject verb agreement. Besides that, Aishah also could use other verbs correctly in the final draft such as 'He likes...' (Sentence 22), 'Although he takes...' (Sentence 23) and 'My father does...' (Sentence 24) compared to the first draft where all the sentences are in plural form.

\section{DISCUSSION}

Overall, it can be seen that the interaction with the teacher was able to show the participants how are readers would react to their writing. In addition, it showed the participants the fallacy of assuming too much in writing and the need to provide more detail, or where they were being repetitious of ideas and get off the track. This finally led to the changes in the learners' drafts by including suggestions or comments proposed by the teacher during the discussion. Changes could be seen in terms of words and elaboration in the second draft throughout the learning process until the compositions were produced. The learners' writing development in this study can thus be illustrated in Figure 1 below:

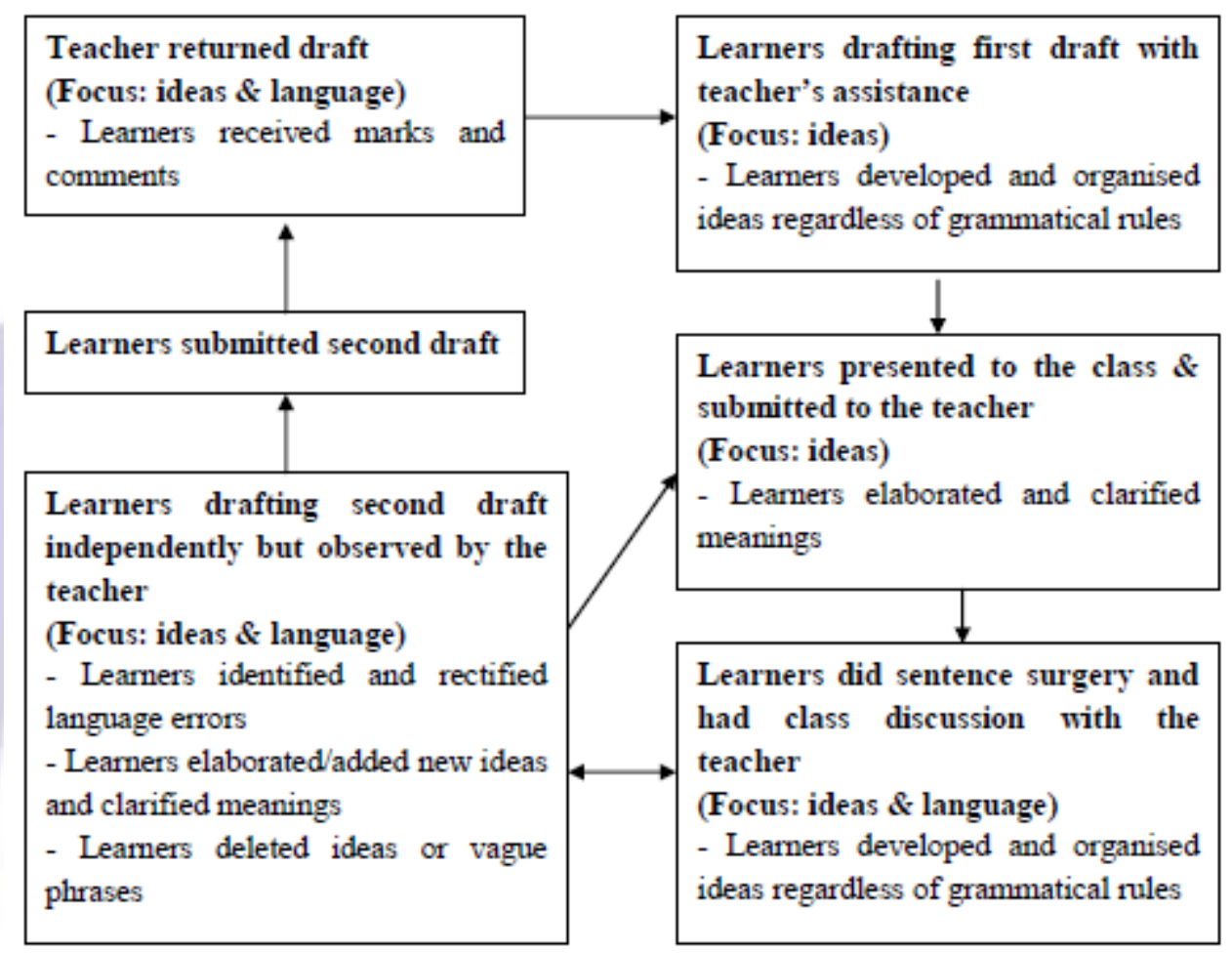

Figure 1 The writing development of the three participants in this study

Changes in the learners' writing after given assistance as shown above indirectly depicted the zone of proximal development (ZPD) stages proposed by Vygotsky where learners move from dependent learners (where they need assistance) and gradually become independent towards the end when they are able to conceptualise and understand the meaning behind the activities. In this study, the teacher's questioning and feedback had the learners changed their idea presentation when they realised their ideas were not clearly understood by readers. In both Farah and Haslina's cases, the teacher did not give any direct answer to clear up their ambiguous ideas, but the teacher only gave indications of what were the errors and the reasons why they were wrong. Based on the feedback, both learners independently tried to improve their writing by changing and deleting certain words which they initially believed able to convey their intended ideas. This process indirectly showed the movement from stage 1 (where assistance provided by more capable others), stage II (where the learners tried to assist themselves) to stage III (internalisation took place) of the ZPD model. Thus, it showed the teacher's assistance of questioning and commenting were actually able to gradually move the high and average self-efficacy writers throughout the process of writing to independent writers. As McCarthey, et al. (2004:353) has pointed out that "when the teacher and learners developed intersubjectivity, the learners were more likely to internalise the classroom discourse and use it in writing".

In conclusion, the writers were able to revise their writing based on the suggestions or comments given by the teacher. Based on the finding, it can be concluded that they made attempts to address the comments even though the revision made in response to these comments generally had; i) minimal changes; ii) led to changes with mixed effects (i.e. changed draft using the teacher's input; iii) changed drafts without the teacher's input; or iv) did not change their drafts at all although mistakes had been discussed). To be specific, the writers firstly changed their word choices or add elaboration 
when the teacher found unsuitable words and insufficient ideas. Secondly, the writers even changed their ideas when the reader (the teacher) questioned and did not accept their explanation. Obviously, the writers used the teacher's feedback to direct themselves to write or elaborate more. In addition, the teacher's assistance affected the way they valued and developed their voices as writers. These findings relate to the concept of internalisation by Vygotsky. In the questioning and commenting session, the readers gave feedback and evaluate the writers' writing. For example, during the class discussion on sentence surgery, the teacher and other peers commented that they did not like how Farah presented her ideas in the introduction of the essay "How to score As in the SPM examination". Farah later improvised her introduction by considering the teacher's example and her peers' suggestion. This implies that the writer eventually internalised the feedback from her social interaction to further improve her writing. To use Vygotsky's term, there is a shift from intrapsychological functioning (between people) to intrapsychological (within an individual mind) (Smith, 1997). However, when too much assistance was provided, learners will not be able to internalise and perform independently towards the end. This is because it leads to the changes of drafts only by using the teacher's input. Though the learners in this study were able to write second draft without errors, there was no transfer of knowledge and skills in writing, but only lifting from the teacher's words. This can be seen in Aishah's composition where she relied heavily on the teacher's written suggestions and followed strictly the suggestions given. Even though there was a comment given which required her to elaborate certain sentences in her first draft, she ignored it and opted for only written suggestion given. Thus, there was no new idea development in her second draft in comparison to her peers Farah and Haslina, who improved their ideas development and language aspect.

\section{CONCLUSION}

The discussion and interaction between teacher and students in which students critically read and discuss their drafts had shown differences between the first and the final drafts in this research. Learners were found to make certain changes in their revised draft when they were involved in the process of their learning. Firstly, by discussing with their teacher, it helped the learners to clarify ambiguous idea. Their teacher who acted as readers gave comments or asked questions when she did not understand what the writer was trying to convey in their composition. During discussion, the teacher asked questions which indirectly helped and gave the writer an idea on how to elaborate their writing to make it clearer. Furthermore, it was found that the learners in the research changed unsuitable words when their teacher did not understand or agreed with their choices of words. Overall, in the process of interaction with the teacher, learners use language to channel their knowledge and opinions, and work out any differences that might occur in the process of learning. In addition, it is constructed as a purposeful strategy where learners need to communicate, to understand and to be understood as well as acquire new knowledge. In relation to this, this strategy utilizes the model proposed by Flower and Hayes and also the theory by Vygotsky such as scaffolding and Zone Proximal Development.

\section{REFERENCES}

[1] Assoc Prof Dr. Padmani Mildred Thiyagarajah. (2003). Learning English in Malaysian rural secondary schools: Difficulties, learning style \& strategies \& motivation. Retrieved 28 April 2009 from http://lc03.commongroundconferences.com/ProposalSystem/Presentations/P000844.html

[2] Chitravelu, N., Sithamparam, S. \& Teh Soo Choon. (2005). ELT Methodology: Principles and practice. Shah Alam: Penerbit Fajar Bakti Sdn.Bhd.

[3] Daniels, H. (2001). Vygotsky and pedagogy. London: RoutledgeFalmer.

[4] Donovan, C.A. \& Smolkin, L.B. (2008). Children's understanding of genre and writing development. In Charles MacArthur, Steve Graham, and Jill Fitzgerald (Eds.). Handbook of writing research, pp 131-143. New York: The Guilford Press.

[5] Englert, C.S., Mariage, T.V \& Kailoniie, D. (2008). Tenets of sociocultural theory in writing instruction research. In Charles MacArthur, Steve Graham, and Jill Fitzgerald (Eds.). Handbook of writing research, pp 208-221. New York: The Guilford Press.

[6] Fraenkel, J.R. \& Wallen, N.E. (2001). Educational Research: A Guide to the Process. Mahwah, NJ: Lawrence Erlbaum Associates.

[7] Gallagher, C. (1999). Vygotsky's sociocultural theory. Retrieved 15 May 2008 from http://www.muskingum.edu/ psych/psycweb/history/vygotsky.htm.

[8] Gallimore, R. \& Tharp, R. (2000). Teaching mind in society. In L. Moll (Ed.). Vygotsky and education: Instructional implications and social applications of sociohistorical psychology, pp175-205. New York: Cambridge University Press.

[9] Lantolf, J.P. \& Thorne, S.L. (2006). Sociocultural theory and the genesis of second language development. Auckland: Oxford University Press.

[10] Lantolf, J.P.(2000). Introducing sociocultural theory. In J.P. Lantolf (Ed.). Sociocultural theory and second language learning, pp1-26. Oxford: Oxford University.

[11] Malaysia Examinations Syndicate, Ministry of Education Malaysia (2008). Data Keputusan Peperiksaan PMR dan SPM bagi tujuan kajian. 


\section{ISSN 2278-7690}

[12] Ministry of Education, Malaysia (2007). Manual Definisi Variabel EMIS. Putrajaya: Bahagian Perancangan \& Penyelidikan Dasar Pendidikan.

[13] Norazman Abdul Majid, Faruk Muhammad \& Fatimah Puteh (2005). English language literacy in rural community setting: An analysis of the environment to encourage and sustain the development of English language learning outside the classroom. Skudai, Johor: University of Technology Malaysia Research Management Centre.

[14] Ratnawati Mohd Asraf \& Ismail Sheikh Ahmad (2003). Promoting English language development and reading habit among students in rural schools through the Guided Extensive Reading program. Retrieved 5 October 2009 from http://www.nflrc.hawaii.edu/RFL/October2003/mohdasraf/mohdasraf.html

[15] Samuel, R. \& Zaitun Bakar (2008). The effectiveness of 'VELT' in promoting English language communication skills: A case study in Malaysia. International Journal of Education and Development using ICT, 4(3), 1-14 (Online). Retrieved 5 October 2009 from http://ijedict.dec.uwi.edu/viewarticle.php?id=559\&layout=html

[16] Smith, A. (1997). Understanding children's development : A New Zealand Perspective. (3 $3^{\text {rd }}$ ed.). New Zealand : Bridget Williams Books Ltd.

[17] Smith, J. (1997). How people learn to write. New Zealand: Longman.

[18] Tharp, R. (1994). Research knowledge and policy issues in cultural diversity and education. In B. McLeod (Ed.), Language and learning: Educating linguistically diverse students, pp.129-167. Albany, NY: State University of New York Press.

[19] Tharp, R.G. \& Gallimore, R. (1988). Rousing minds to life: Teaching, learning, and schooling in social context. Cambridge: Cambridge University Press.

[20] UPSR verdict tomorrow. Razali: Results will reveal if rural reading programme is successful. 2008. The Sun, 12 November: 19.

[21] Wiersma, W.\& Jurs, S.G. (2005). Research methods in education: An introduction ( $8^{\text {th }}$ Edition). New York: Pearson Education, Inc.

[22] Willhelm, J., Baker, T. \& Dube, J. (2001). Strategic reading: Guiding students to lifelong literacy. New Hamphshire, USA: Heinemann. Retrieved 22 July 2008 from http://www.myread.org/scaffolding.htm.

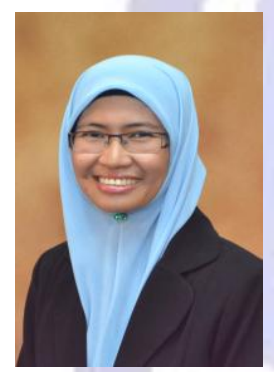

\section{Author' biography with Photo}

Dr llyana Jalaluddin completed her B.Ed at Otago University New Zealand, while her M.Ed and PhD in Teaching of English as a Second Language (TESL) at Universiti Malaya and Universiti Kebangsaan Malaysia respectively.She was an English teacher in secondary schools in Malaysia previously and now resides in Selangor as a senior lecturer at Universiti Putra Malaysia focusing on teaching and carrying out research in Education and Second Language Acquisition field. 